\title{
PRELIMINARY SURVEY OF SPIDERS (ARANEAE: ARACHNIDA) IN SADAR TEHSIL OF AURAIYA DISTRICT, UTTAR PRADESH, INDIA
}

\author{
Bindra Bihari Singh ${ }^{1 *}$ and Yogesh Babu Dixit ${ }^{2}$ \\ ${ }^{1}$ Department of Agricultural Entomology \\ Janta Mahavidyalaya Ajitmal, Auraiya (U.P.), India \\ ${ }^{2}$ Post Graduate Department of Zoology \\ Janta Mahavidyalaya Ajitmal, Auraiya (U.P.), India \\ *Corresponding author: singhbbjmv@gmail.com
}

\begin{tabular}{|l} 
Article Info: \\
Research Art \\
Received \\
$\mathbf{2 5 . 0 1 . 2 0 2 2}$ \\
Reviewed \\
$\mathbf{2 0 . 0 2 . 2 0 2 2}$ \\
Accepted \\
$\mathbf{2 8 . 0 2 . 2 0 2 2}$
\end{tabular}

\begin{abstract}
A total of 76 species of spiders described under 48 genera belonging to 16 families were recorded in the sadar subdistrict of district Auraiya, Uttar Pradesh, India during the present study. Among them, the family Araneidae included more than one-third of the species (38.15\%) followed by Lycosidae (11.84\%) and Salticidae (10.52\%) and rest of the families comprised less than 10\% of the species composition. Four species, Cyclosa moonduensis, Cyclosa mulmeinensis, Gibbaranea bituberculata and Pardosa pusiola were recorded for the first time in Uttar Pradesh. Orb weavers $(50.0 \%)$ formed the most dominant guild followed by ground runners (18.1\%). Stalkers (15.3\%), and space or 3D web builders (8.3\%), ambushers and foliage runners (4.2\% each) and ambushers (5.1\%) were less common in the study area. Such surveys are vital for conservation of these arthropods which are helpful for natural pest control and regarded as good indicators of habitat quality.
\end{abstract}

Keywords: Araneae, Auraiya, Fauna report, Sadar tehsil, Spiders.

Cite this article as: Singh B.B. and Dixit Y. B. (2022). Preliminary Survey of Spiders (Araneae: Arachnida) in Sadar Tehsil of Auraiya District, Uttar Pradesh, India. International Journal of Biological Innovations. 4(1): 83-93. https://doi.org/10.46505/IJBI.2022.4109.

\section{INTRODUCTION}

The spiders belong to order Araneae, class Arachnida, subphylum Chelicerata of the phylum Arthropoda, the largest phylum of Kingdom Animalia (Verma and Prakash, 2020). Spiders can easily be identified from other arthropods like insects (Hexapoda: Arthropoda) in having eight legs rather than six and in having the body divided into two parts (cephalothorax, abdomen) rather than three (head, thorax, abdomen). Spiders have the ability to manufacture silk to build webs for trapping and wrapping preys. The appearance, ecology and biology of spiders are highly diverse. Some spiders are active hunters and some construct silk webs to capture preys. Spiders are cosmopolitan (except Antarctica). Almost all spiders are predators, mostly feeding entirely on other arthropods, especially insects (VasconcellosNeto et al., 2017; Cotes et al., 2018). Indeed, they are potential biocontrol agents as they are relatively resistant to starvation and desiccation. Like honey bees, if spiders were to disappear from the face of the earth, humans would only survive 
a few years due to food shortages due to pest infestations. The spiders also serve as a food source for an extremely diverse complex of predators-parasitoids-parasites, amphibians, snakes, lizards, birds, shrews, mice, bats, fish etc. In spite of being ecologically significant, the spiders are least accepted because of commonness of spider fear in public (Zvaríková, 2021). The order Araneae consists of 49,885 species in 4,238 genera belonging to 131 families (WSC, 2022). Despite recent researches on the faunistic biodiversity of spiders in India, their recorded number is less as compared to other parts of the world. India having a very rich biodiversity and a tropical climate with biodiversity hotspots, has the best account so far only 1892 species belonging to 485 genera in 60 families (Caleb and Sankaran, 2022), while, Singh and Singh (2021a) listed 2344 species described under 596 genera comprising 65 families, though in this list, several species were considered cases of misidentification by the authors. However, there exist many species in the wild and museums that still await description and classification. Despite recent research works on the diversity and distribution of spiders in India, their number is insufficient as compared to the other parts of the world.

Despite the ecological importance and diversity, spiders are underrepresented in conservation policies in comparison to other groups throughout the world (Milano et al., 2021). For the conservation of biodiversity of the spiders of any region of the world, their proper documentation is vital as it helps in monitoring the rate of loss of species in future. Preparation of checklists of species is an essential component of systematic documentation. Hence, in view of increasing intensity of anthropogenic and climatic threats (climate change, grazing, deforestation/habitat loss, forest fires, scarcity of water, use of pesticides in agriculture, Indian agricultural practices such as burning of litter and waste of crop remains and ploughing during late May, use of mosquito repellents and larvicidal pesticides to control malaria, urbanization, development of road networks and trade (Vankhede, 2011; Verma, 2017) to biodiversity, a cataloguing and appropriate documentation of biodiversity, especially on ignored groups like spiders, is desirable immediately (Singh and Singh, 2021b). Several workers including Singh and Singh (2020, 2021c, 2022a, 2022b), Singh et al. $(2020,2021)$, Singh (2021), etc. have documented the diversity of spider fauna of different parts of India including Uttar Pradesh. Recently, the authors have documented the spider fauna of Bidhuna subdistrict (Dixit and Singh, 2022a) and Ajitmal subdistrict (Dixit and Singh, 2022b) of Auraiya district. In this article, spider diversity of the sadar tehsil of Auraiya district was studied and presented.

\section{MATERIALS AND METHODS}

\section{Site Description: Auraiya tehsil}

The study area is sadar tehsil of Auraiya district of Uttar Pradesh. Auraiya district (latitude: $26^{\circ} 21^{\prime}$ to $27^{\circ} 10^{\prime} \mathrm{N}$; longitude: $78^{\circ} 45^{\prime}$ to $79^{\circ} 45^{\prime} \mathrm{E}$ ) is located in the south-western part of Kanpur division. North of this district lies district Kannauj, on the East Kanpur Dehat, on the south is district Jalaun, while on the west is district Etawah. River Yamuna and Kunwari separate the district from Jalaun. Auraiya was created in September, 1997 be separating two tehsils, Auraiya and Bidhuna of district Etawah. In 2014, Ajitmal block was created as subdistrict of Auraiya. The Auraiya district covers an area of $2,054 \mathrm{~km}^{2}$, of which more than one-third is rural area. Two rivers, Yamuna $(112 \mathrm{~km})$ and Senger flow through the district. It lies entirely in the Indo-Gangetic Plain.

Area under forest is insignificant and only few patches of small forests are spread in Auraiya tehsil. There are several parks, temples and gardens in Auraiya tehsil. There are 410 villages in the tehsil Auraiya. The climate of the tehsil is humid subtropical. The winter season from midNovember to February is followed by the summer season from March to mid-June. The period from mid-June to the end of September is the southwest monsoon season and the October and the first half of November constitute the postmonsoon season. Summer is very hot, temperature may reach up to $46^{\circ} \mathrm{C}$ while in winter it may drop to $3{ }^{\circ} \mathrm{C}$. More than $80 \%$ of the total annual rainfall is received during July to October. Different places of the tehsil were chosen for sampling in different habitats during August, 2018 to December, 2021 (Figure 1). 


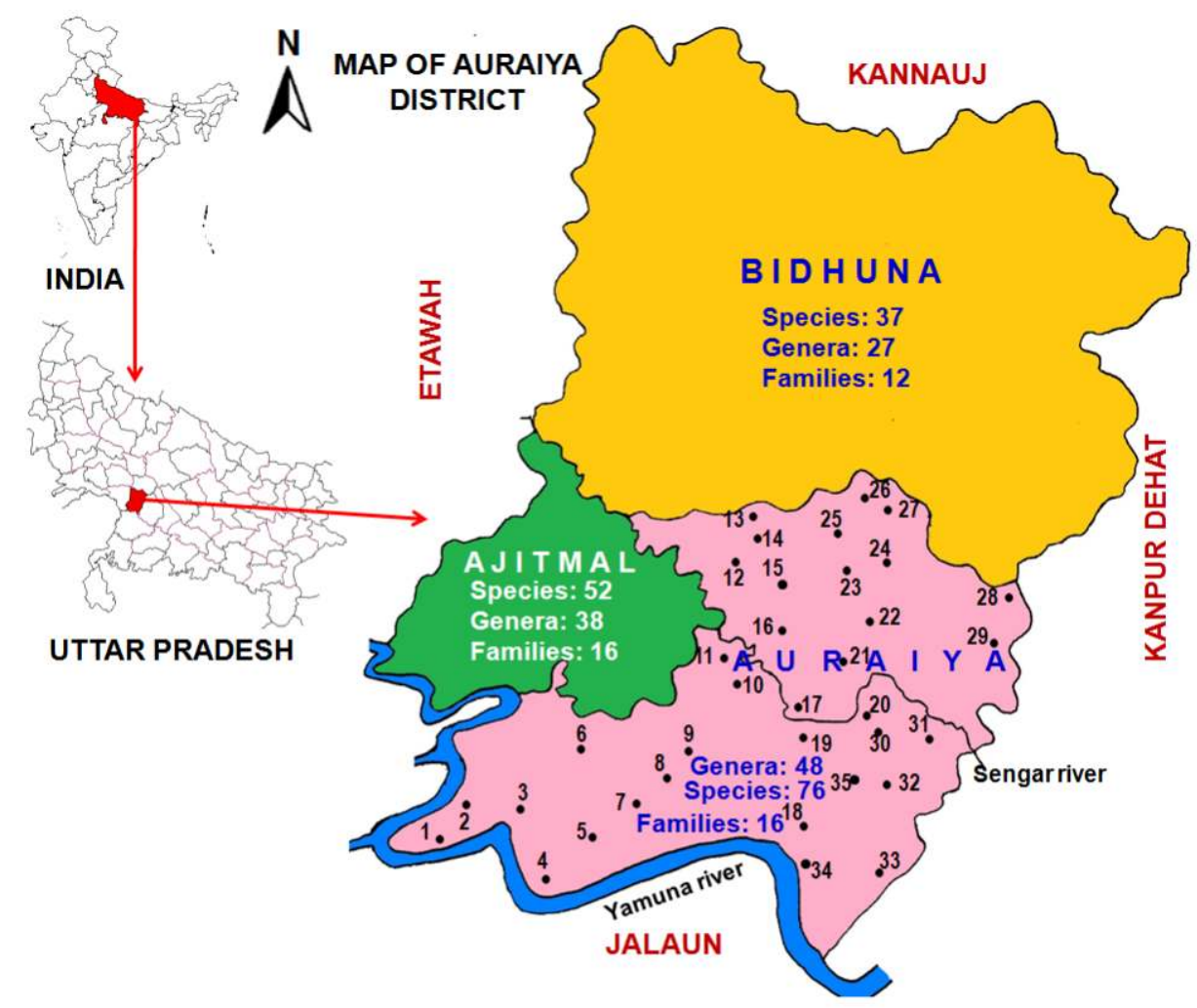

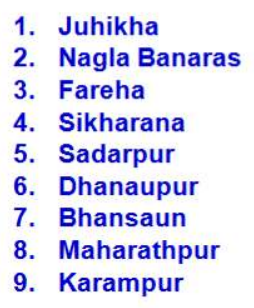

1. Juhikha

2. Nagla Banaras

3. Fareha

6. Dhanaupur

. Bhansaun

9. Karampur

10. Malakpur
11. Garha Manik Chandra
12. Phaphund
13. Khanpur Phaphund
14. Khagipur
15. Purwa Bhawani
16. Ata
17. Sherpur Sariya
18. Auraiya

28. Kanchausi

29. Jamauli

30. Sudanipur

31. Dharampur

32. Sadhuapar

33. Bhagautipur

34. Bhadaura

35 . Shabadiya

Figure 1: Location of study site in sadar tehsil of Auraiya district, Uttar Pradesh. Number of species, genera and families of spiders are mentioned in different tehsil of the district.

\section{Sampling Methods}

Collection of spider specimens was made from 35 locations representing various habitats viz. Ata, Auraiya, Bhadaura, Bhagautipur, Bhansaun, Chichauli, Dhanaupur, Dharampur, Dibiyapur, Fareha, Gail Gaon, Garha Manik Chandra, Jamauli, Jamuha, Juhikha, Kakarkhurd, Kakor, Kanchausi, Karampur, Khagipur, Khanpur, Maharathpur, Malakpur, Malhepur, Merakhpur, Nagla Banaras, Phaphund, Purwa Bhawani, Sadarpur, Sadhuapar, Seehpur, Shabadiya, Sherpur Sariya, Sikharana, Sudanipur (Figure 1) of Auraiya subdistrict of Auraiya district, Uttar Pradesh during August, 2018 to December, 2021.

Efforts were made to search for spiders from as many kinds of habitats as possible, such as grasslands; rice, maize and sugarcane fields; road side grasses, shrubs, trees; railway tracks; gardens and parks; college, school and temple campuses; human dwellings, garages etc. at several places in both blocks of Auraiya subdistrict: Auraiya and Bhagyanagar (Figure 2). Litter, straw, other detritus, stones and logs were removed carefully for catching the hiding spiders. Area near water hills and hillocks, gardens, waste lands were also searched. Standard sampling protocols for spider collection were adopted in different selected sampling spots. The detailed descriptions of the collection techniques (Singh and Singh, 2014) are as follows:

(I) Using sweep net: The foliage spiders from low level vegetation of shrubs (up to $2 \mathrm{~m}$ in height) were sampled by this method. The sweep net consists of a $90 \mathrm{~cm}$ handle; $40 \mathrm{~cm}$ ring and the collection were poured on white canvas. The net was emptied at regular intervals to avoid loss and destruction of the specimen. During collection sweep net was moved back and forth to cover all 

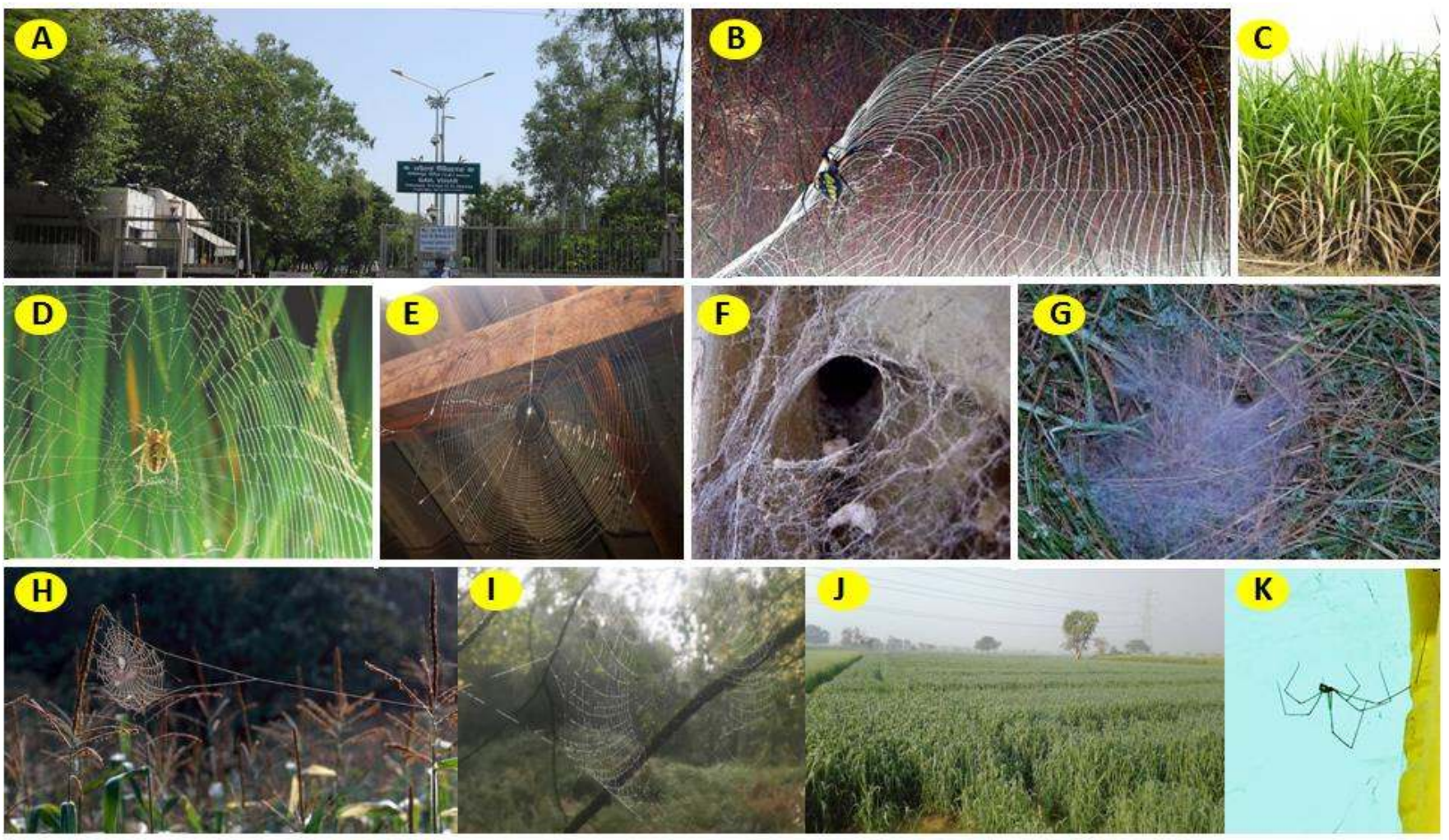

J
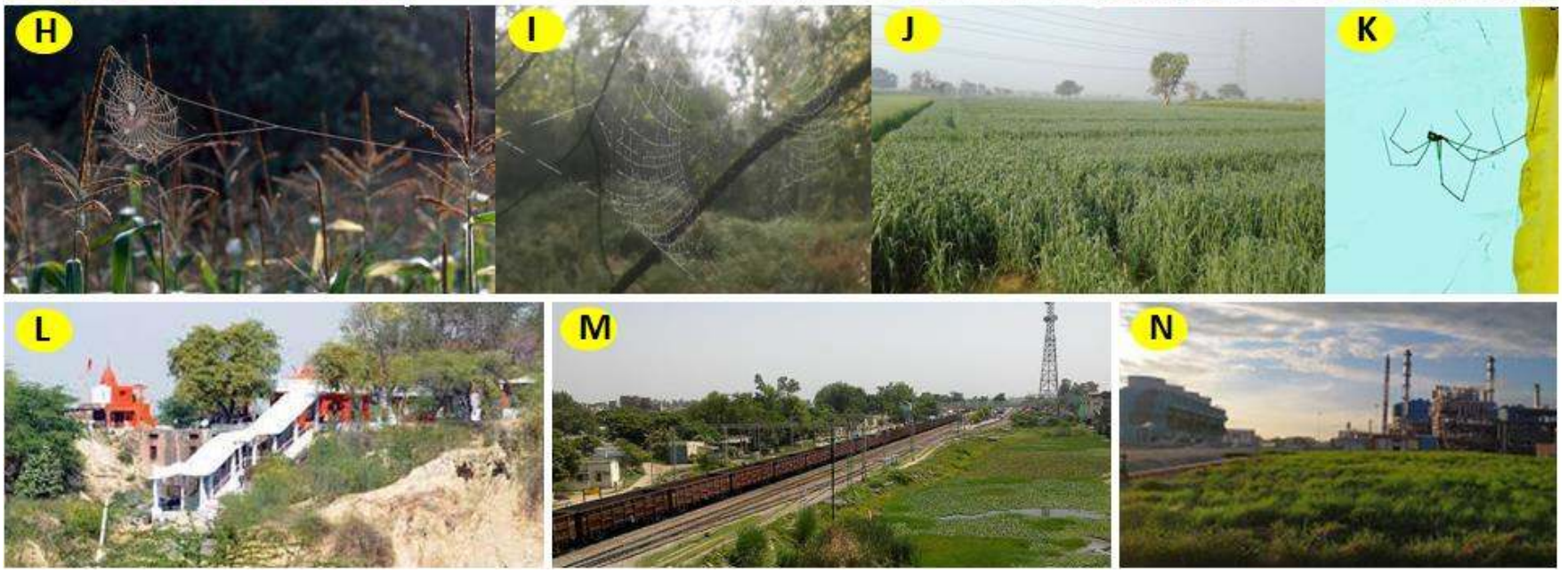

Figure 2. Some collection sites: A. Gail Bihar, Dibiyapur; B. Roadside shrubs, Ata; C. Sugarcane field, Karampur; D. Rice field, Fareha; E. House roof, Phaphund; F. Road side trees, Kakor; G. Roadside shrubs, Bhagautipur; H. Maize field, Seehpur; I. Garden, Auraiya; J. Wheat field, Malhepur; K. House corner wall, Khagipur; L. Mangla Kali Mandir, Auraiya; M. Railway line side, Phaphund; and N. Gail industrial area, Gail Gaon.

ground layer herbs and shrubs till all vegetation in the sampling plots were swept thoroughly.

(ii) Ground hand collection: This method of sampling is used to collect the spiders, which are found to be visible in the ground, litter, in broken logs, etc.

(iii) Aerial hand collection: This method was used to collect web-building and free-living spiders on the foliage and stems of living or dead shrubs, high herbs, tree trunks etc.

(iv) By beating vegetation: The spiders were collected by beating the vegetation with a stick and collecting the samples on a cloth. The method is used to sample spiders living in the shrub, high herb vegetation, bushes, and small trees and branches.

(v) Litter sampling: Litter sampling involved sorting of spiders from the litter collection tray.

(vi) By using aspirator: Small spiders were captured by placing an aspirator above or near the spider and sucking it up with mouth.

(vii) Pitfall traps: These traps were commonly used for the collection of ground-dwelling spiders particularly males. For this, the plastic bowls of $10 \mathrm{~cm}$ diameter and $15 \mathrm{~cm}$ depth were immersed in the ground so that the top is flush with the ground. The bottom of the bowl was filled with ethylene glycol. The traps were kept at 
different places in fields and farms and trapped specimens were collected after 24 hours.

Web pattern and habitat types were recorded with every encounter. The collected spiders were placed separately in vials (as they are cannibals) having $70 \%$ ethyl alcohol with few drops of glycerin for further taxonomic treatment. The specimens were placed with proper labels indicating locality, date of collection and other details like habitat, behaviour etc.

\section{Identification}

The examination of spiders was done under a stereo-zoom microscope with magnification up to 500x. The adult spiders were identified using available literatures (Tikader, 1980, 1982, 1987), Tikader and Malhotra (1980), Barrion and Litsinger (1995), websites, etc. and subject experts. Some of the immature stages could not be identified and ignored.

\section{RESULTS AND DISCUSSION}

Several hundreds of individuals of spiders belonging to 76 species under 48 genera and 16 families were collected from different areas of Auraiya subdistrict of Auraiya district, Uttar Pradesh. Table 1 display the species diversity of the collected spiders. Out of 16 families of spiders recorded, Araneidae includes 29 species of spiders (38.15\%) followed by Lycosidae (11.84\%), Salticidae (10.52\%) and rest of the families consist of less than $10 \%$ of the total species recorded. Pholcus phalangioides (Fuessli, 1775) was recorded at 18 places out of 35 places selected for spider collection followed by Argiope pulchella Thorell, 1881 (15 places); Argiope anasuja Thorell, 1887 (14 places); and Stegodyphus sarasinorum Karsch, 1892 were recorded at 10 places out of 17 places selected for the survey programme followed by Argiope anasuja Thorell, 1887 and Lycosa mackenziei Gravely, 1924 (8 places), Cyclosa insulana (Costa, 1834) and Cyrtophora cicatrosa (Stoliczka, 1869) (7 places); Argiope anasuja Thorell, 1887; Cyrtophora citricola (Forsskål, 1775) and Plexippus paykulli (Audouin, 1826) (8 places each) and other species less than at 7 or less places. Among 76 species of spiders, 15 species were observed only at two places while three species were recorded from only one place. Maximum number of species (28 species) were collected from Phaphund (college campus, agricultural fields, roadsides, railway track sides, temple area etc.) followed by Auraiya and Dibiyapur (16 species each), Jamuha (14 species), and less number of species in other places. Out of 76 species of spiders recorded in Auraiya, 31 species were also recorded in Bidhuna and Ajitmal subdistricts of Auraiya district and 19 species were recorded in Ajitmal subdistricts and not in Bidhuna subdistrict (Dixit and Singh, 2022b). Twenty five species were not observed in both the subdistricts. Four species, Cyclosa moonduensis Tikader, 1963, Cyclosa mulmeinensis (Thorell, 1887), Gibbaranea bituberculata (Walckenaer, 1802) and Pardosa pusiola (Thorell, 1891) were recorded for the first time in Uttar Pradesh (Singh and Singh, 2022b). Remaining 68 species of spiders were recorded in other districts of Uttar Pradesh, viz. Agra (Lawania and Mathur, 2014a,2014b), Gonda (Singh et al., 2021), Gorakhpur, Kushinagar and Deoria (Singh and Singh, 2014), Lakhimpur Khiri (Hore and Uniyal, 2008a, 2008b, 2008c), Lucknow (Kumar et al., 2017a), Mathura (Lawania and Mathur, 2014c), Maharajganj and Siddharthnagar (Sharma and Singh, 2018a, 2018b), Unnao (Kumar et al., 2017b) and few other districts (Singh and Singh, 2022a).

\section{Foraging guilds}

The collected spiders were grouped into foraging guilds according to Uetz et al. (1999). These guilds were orb weavers (Araneidae, Tetragnathidae, Uloboridae), stalkers (Oxyopidae and Salticidae), ground runners (Lycosidae, Gnaphosidae), foliage runners (Clubionidae, Sparassidae), space or 3D builders (Theriidae, Pholcidae), and ambushers (Thomisidae). Orb weavers (50.0\%) formed the most dominant guild followed by ground runners (18.1\%). Stalkers (15.3\%), and space or 3D web builders (8.3\%), ambushers and foliage runners $(4.2 \%$ each) and ambushers (5.1\%) were less common in the study area (Figure 3). These observations are in accordance with studies in other districts (Singh 


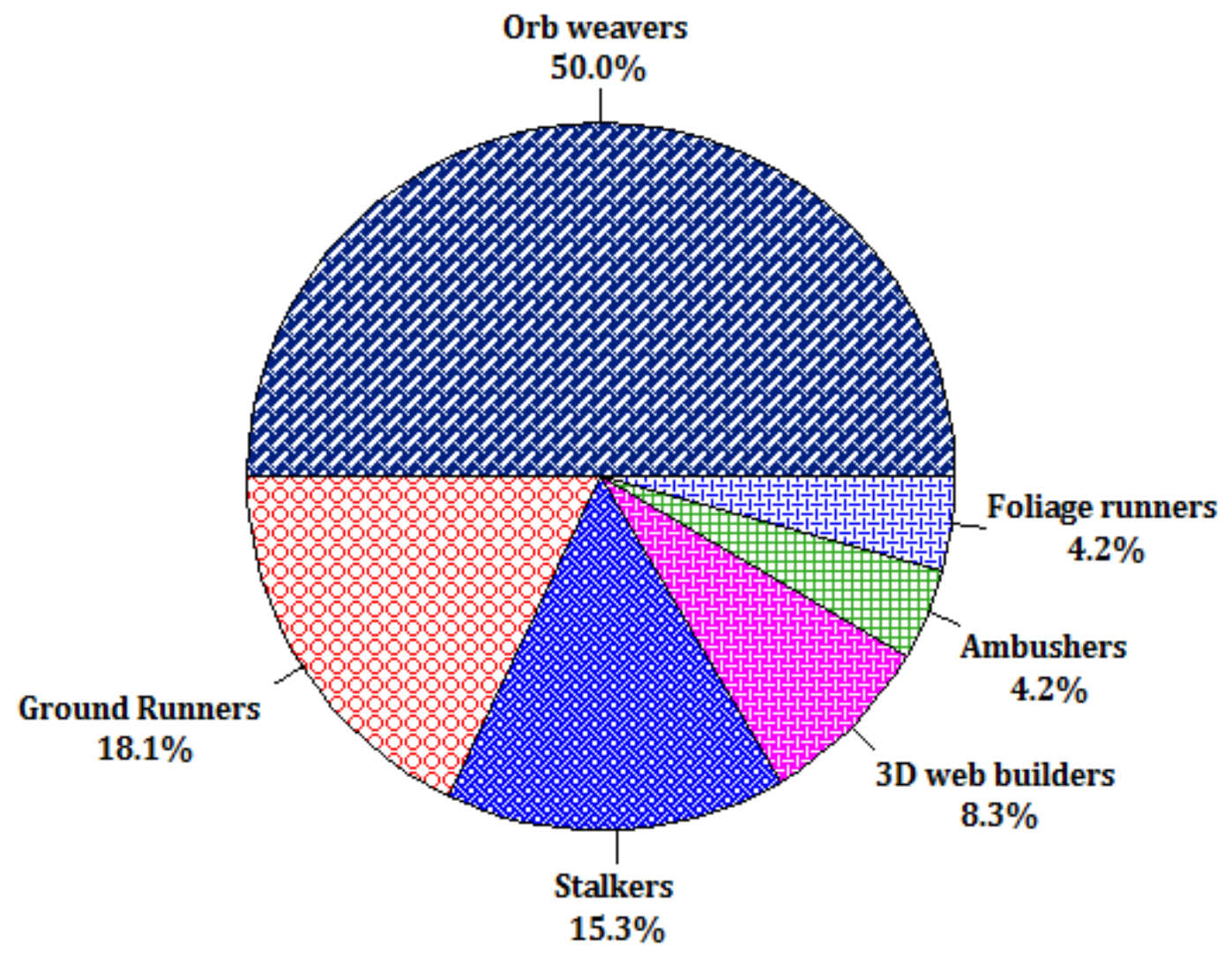

Figure 3: The foraging guild structures of the spiders collected from Auraiya subdistrict of Auraiya district, Uttar Pradesh.

Table 1: List of spider diversity of Auraiya subdistrict of Auraiya district, Uttar Pradesh.

\begin{tabular}{ll}
\hline Family/Species & Family/Species
\end{tabular}

\section{Araneidae}

1. Araneus diadematus Clerck, 1757

2. Argiope pulchella Thorell, 1881

3. Argiope anasuja Thorell, 1887

4. Argiope aemula (Walckenaer, 1842)

5. Argiope luzona (Walckenaer, 1837)

6. Bijoaraneus mitificus (Simon, 1886)

7. Cyclosa bifida (Doleschall, 1859)

8. Cyclosa confraga (Thorell,1892)

9. Cyclosa hexatuberculata Tikader, 1982
Bhadaura, Dhanaupur, Dibiyapur, Sadarpur, Sudanipur

Bhansaun, Gail Gaon, Jamuha, Juhikha, Kakarkhurd, Kakor, Kanchausi, Khagipur, Maharathpur, Khanpur Phaphund, Merakhpur, Phaphund, Purwa Bhawani, Seehpur, Sadhuapar

Auraiya, Dhanaupur, Dibiyapur, Garha Manik Chandra, Jamauli, Karampur, Phaphund, Shabadiya

Auraiya, Gail Gaon, Jamuha, Juhikha, Kakarkhurd, Kakor, Kanchausi, Khanpur Phaphund, Malakpur, Merakhpur, Purwa Bhawani, Seehpur, Sherpur Sariya, Sadhuapar

Bhadaura, Jamuha

Bhansaun, Gail Gaon, Juhikha, Sikharana Ata, Dibiyapur, Jamauli

Auraiya, Bhadaura, Jamauli, Kakor, Kanchausi Phaphund, Dibiyapur 


\section{Family/Species}

10. Cyclosa insulana (Costa, 1834)

11. Cyclosa moonduensis Tikader, $1963^{*}$

12. Cyclosa mulmeinensis (Thorell, 1887)*

13. Cyrtophora cicatrosa (Stoliczka, 1869)

14. Cyrtophora citricola (Forsskål, 1775)

15. Eriovixia excelsa (Simon, 1889)

16. Eriovixia laglaizei (Simon, 1877)

17. Gasteracantha diadesmia Thorell, 1887

18. Gasteracantha kuhli C.L. Koch, 1837

19. Gibbaranea bituberculata (Walckenaer, 1802)*

20. Larinia chloris Audoin (1826)

21. Larinia kanpurae Patel \& Nigam, 1994

22. Larinia phthisica (L. Koch, 1871)

23. Macracantha hasselti (C. L. Koch, 1837)

24. Neoscona dhruvai Patel \& Nigam, 1994

25. Neoscona mukerjei Tikader, 1980

26. Neoscona nautica (L. Koch, 1875)

27. Neoscona theisi (Walckenaer, 1842)

28. Nephila pilipes (Fabricius, 1793)

29. Thelacantha brevispina (Doleschall, 1857)

2. Cheiracanthidae

30. Cheiracanthium danieli Tikader, 1975

\section{Clubionidae}

31. Clubiona drassodes O. P.-Cambridge, 1874

\section{Eresidae}

32. Stegodyphus sarasinorum Karsch, 1892

\section{Gnaphosidae}

33. Drassodes carinivulvus Caporiacco, 1935

34. Megamyrmaekion caudatum Reuss, 1834

35. Poecilochroa tikaderi Patel, 1989

36. Urozelotes rusticus (L. Koch, 1872)

\section{Family/Species}

Gail Gaon, Kakarkhurd, Khagipur, Maharathpur, Sadarpur, Sudanipur

Phaphund, Sadarpur, Sudanipur

Auraiya, Bhansaun

Chichauli, Gail Gaon, Kakor, Kanchausi, Malakpur, Phaphund, Sadhuapar, Sherpur Sariya

Auraiya, Bhadaura, Kakarkhurd, Sikharana

Bhagautipur, Dharampur, Karampur, Phaphund, Khanpur Phaphund,

Dibiyapur, Gail Gaon, Phaphund

Bhadaura, Dhanaupur

Ata, Chichauli, Garha Manik Chandra, Kakor, Kanchausi

Jamuha, Phaphund

Auraiya, Dibiyapur

Auraiya, Bhansaun

Dhanaupur, Gail Gaon, Sikharana

Bhansaun, Dharampur, Garha Manik Chandra, Sadhuapar

Bhagautipur Auraiya

Auraiya, Jamuha, Phaphund

Jamuha, Kakarkhurd, Karampur, Phaphund

Dharampur, Kakor, Kanchausi, Phaphund,

Sadarpur, Sudanipur

Bhansaun, Chichauli, Malakpur, Sherpur Sariya

Dibiyapur, Phaphund, Sikharana

Auraiya, Bhagautipur, Dibiyapur, Khagipur, Maharathpur, Khanpur Phaphund, Seehpur

Auraiya, Dhanaupur, Jamuha

Bhadaura, Juhikha, Karampur, Phaphund, Shabadiya

Dibiyapur, Jamuha, Phaphund

Auraiya, Gail Gaon

Auraiya, Garha Manik Chandra

Ata, Juhikha, Phaphund, Sadarpur, Sudanipur 


\section{Family/Species}

\section{Hersiliidae}

37. Hersilia savigny Lucas, 1836

\section{Lycosidae}

38. Hippasa agelenoides (Simon, 1884)

39. Hippasa greenalliae (Blackwall, 1867)

40. Hippasa holmerae Thorell, 1895

41. Lycosa mackenziei Gravely, 1924

42. Lycosa tista Tikader, 1970

43. Pardosa pseudoannulata

(Bösenberg \& Strand, 1906)

44. Pardosa pusiola (Thorell, 1891)*

45. Pardosa sumatrana (Thorell, 1890)

46. Wadicosa fidelis (O.P.-Cambridge, 1872)

\section{Oxyopidae}

47. Oxyopes birmanicus Thorell, 1887

48. Oxyopes javanus Thorell, 1887

49. Oxyopes shweta Tikader, 1970

\section{Philodromidae}

50. Philodromus sp. Chichauli, Jamuha, Juhikha

10. Pholcidae

51. Artema atlanta Walckenaer, 1837

52. Crossopriza lyoni (Blackwall, 1867)

53. Pholcus phalangioides (Fuessli, 1775)

\section{Salticidae}

54. Hasarius adansoni (Audouin, 1826)

55. Myrmarachne melanocephala MacLeay, 1839

56. Phintella vittata (C L Koch, 1846)

57. Plexippus paykulli (Audouin, 1826)

58. Plexippus petersi (Karsch, 1878)
Bhagautipur, Chichauli, Garha Manik Chandra, Jamuha

Phaphund, Khanpur Phaphund, Seehpur

Dhanaupur, Jamuha, Malakpur, Sherpur Sariya

Bhansaun, Dibiyapur, Kakarkhurd,

Dharampur, Merakhpur, Phaphund,

Purwa Bhawani

Karampur, Phaphund, Sadhuapar

Dibiyapur, Phaphund

Phaphund, Khanpur Phaphund, Seehpur,

Shabadiya

Juhikha, Kakarkhurd, Kakor, Kanchausi,

Karampur, Phaphund, Sikharana

Auraiya, Malakpur, Sherpur Sariya

Dibiyapur, Phaphund, Sikharana

Ata, Garha Manik Chandra

Bhagautipur, Jamauli, Khagipur,

Maharathpur, Shabadiya

Auraiya, Dibiyapur, Fareha, Garha Manik Chandra, Jamauli, Juhikha, Kakarkhurd, Kakor, Kanchausi, Khanpur Phaphund, Malhepur, Nagla Banaras, Merakhpur, Phaphund, Purwa Bhawani, Seehpur, Sadarpur, Sudanipur

Karampur, Phaphund, Sikharana

Bhadaura, Gail Gaon, Sadhuapar

Jamauli, Jamuha, Kakor, Kanchausi

Dibiyapur, Kakarkhurd, Karampur, Khanpur

Phaphund, Malhepur, Nagla Banaras, Phaphund, Seehpur

Bhagautipur, Khanpur Phaphund, Seehpur 
Family/Species

59. Rhene flavigera (C.L. Koch, 1846)

60. Stenaelurillus lesserti Reimoser, 1934

61. Telamonia dimidiata (Simon, 1899)

\section{Sparassidae}

62. Heteropoda venatoria (Linnaeus, 1767)

63. Olios milleti (Pocock, 1901)

\section{Tetragnathidae}

64. Guizygiella indica (Tikader \& Bal, 1980)

65. Leucauge celebesiana (Walckenaer,1841)

66. Leucauge decorata (Blackwall, 1864

67. Tetragnatha javana (Thorell, 1890)

68. Tetragnatha keyserlingi Simon, 1890

69. Tetragnatha mandibulata Walckenaer, 1842

\section{Theridiidae}

70. Latrodectus hasseltii Thorell, 1870

71. Nihonhimea mundula (L. Koch, 1872)

72. Thwaitesia margaritifera Pickard-Cambridge, 1881

\section{Thomisidae}

73. Camaricus formosus Thorell, 1887

74. Runcinia insecta (L. Koch, 1875)

75. Thomisus sp.

16. Uloboridae

76. Uloborus sp.

${ }^{*}$ First record from Uttar Pradesh.

\section{CONFLICTS OF INTEREST}

The authors declare no conflicts of interest.

\section{ACKNOWLEDGEMENT}

The authors thank the Principal, Janta Mahavidyalaya, Ajitmal, Auraiya, for permission to carry out the present work, to Prof. Rajendra Singh, Department of Zoology, DDU Gorakhpur University, Gorakhpur, U.P. for critically going through the manuscript and giving valuable suggestions for its improvement, to the undergraduate and postgraduate students of Department of Zoology and undergraduate

\section{Family/Species}

Jamauli

Dibiyapur, Malakpur, Sherpur Sariya

Jamuha, Kakarkhurd, Khagipur, Maharathpur

Khanpur Phaphund, Seehpur, Sikharana

Auraiya, Gail Gaon, Jamauli

Jamuha, Phaphund, Sikharana

Auraiya, Fareha, Juhikha

Dhanaupur, Khagipur, Maharathpur

Bhagautipur, Juhikha

Dharampur, Fareha, Kakor, Kanchausi

Garha Manik Chandra

Fareha, Nagla Banaras, Malhepur, Phaphund, Shabadiya

Jamauli, Juhikha, Khanpur Phaphund, Seehpur

Fareha, Gail Gaon, Kakor, Kanchausi, Khagipur, Maharathpur

Dharampur, Kakarkhurd, Malakpur, Sherpur Sariya, Sikharana

Bhadaura, Dharampur, Kakor, Kanchausi, Karampur, Phaphund, Sadhuapar

Fareha, Garha Manik Chandra

Dharampur, Jamauli students of Department of Agricultural Entomology of the college for helping in the collection of the spiders at different places.

\section{REFERENCES}

1. Barrion A.T. and Litsinger J. A. (1995). Riceland spiders of South and Southeast Asia. CAB International, Wallingford, England, 736p.

2. Caleb J.T.D. and Sankaran P.M. (2022). Araneae of India, version 2022. https:// indianspiders.in/ accessed on January, 15, 2022. 
3. Cotes B., González M., Benítez E., De Mas E., Clemente-Orta G., Campos M. and Rodríguez E. (2018). Spider communities and biological control in native habitats surrounding greenhouses. Insects. 9(33): 112.10.3390/insects9010033.

4. Dixit Y.B. and Singh B.B. (2022a). Species diversity of spiders from Bidhuna Tehsil of Auraiya District, Uttar Pradesh, India. International Journal of Zoological Investigations. 8(1): 185-190. https://doi.org/ 10.33745/ijzi.2022.v08i01.02.

5. Dixit Y.B. and Singh B.B. (2022b). Species diversity of spiders (Araneae: Arachnida) from Ajitmal subdistrict of Auraiya District, Uttar Pradesh, India. International Journal of Entomology Research. 7(2): 104-108.

6. Hore U. and Uniyal V.P. (2008a). Diversity and composition of spider assemblages in five vegetation types of the Terai Conservation Area, India. Journal of Arachnology. 36(2): 251-258.

7. Hore U. and Uniyal V.P. (2008b). Effect of prescribed fire on spider assemblage in Terai grasslands, India. Turkish Journal of Arachnology. 1(1): 15-36.

8. Hore U. and Uniyal V.P. (2008c). Use of spiders (Araneae) as indicator for monitoring of habitat conditions in Tarai Conservation Area, India. Indian Forester. 134: 1371-1380.

9. Kumar A., Kanaujia A., Kumar A., Kumar V. and Mishra H. (2017a). Diversity of spiders in Kukrail Reserve Forest, Lucknow, Uttar Pradesh, India. Journal of Environmental Science \& Technology. 4(5): 42-45.

10. Kumar A., Kanaujia A., Kumar A., Kumar V. and Mishra H. (2017b). Araneofauna of Nawabganj bird sanctuary, Unnao, Uttar Pradesh, India. Journal of Entomology \& Zoology Studies. 5(4): 1952-1955.

11. Lawania K.K. and Mathur P. (2014a). Diversity and distribution of spider fauna in and around the Taj Mahal and Taj Protected Forest, Agra (U.P.), India. International Journal of Basic $\mathcal{\sigma}$ Applied Biology. 2(2): 111-114.

12. Lawania K.K. and Mathur P. (2014b). Diversity and distribution of spiders in and around Vrindavan, Mathura, (UP), India. International Journal of Basic \& Applied Biology. 2(2): 115-119.

13. Lawania K.K. and Mathur P. (2014c). On the diversity of spiders in and around SurSarovar Bird Sanctuary, Agra (U.P.), India. International Journal of Basic \& Applied Biology. 2(3): 189-194.

14. Milano F., Blick T., Cardoso P., Chatzaki M., Fukushima C.S., Gajdoš P., Gibbons A.T., Henriques S., Macías-Hernández N., Mammola S., Nentwig W., Nolan M., Pétillon J., Polchaninova N., Řezáč M., M., Sandström J., Smith H., Wiśniewski K. and Isaia M. (2021). Spider conservation in Europe: a review. Biological Conservation. 256: 109020. https://doi.org/10.1016/j.biocon.2021.109020.

15. Sharma A. and Singh R. (2018a). Biodiversity and guild structure of spiders in northeastern Uttar Pradesh. Research Journal of Life Science, Bioinformatics, Pharmaceutical \& Chemical Sciences. 4(4): 525-541.

16. Sharma A. and Singh R. (2018b). Species diversity and guild structure of spiders from Siddharthnagar, Uttar Pradesh, India. Research Journal of Life Science, Bioinformatics, Pharmaceutical \& Chemical Sciences. 4(4): 383-390.

17. Singh A., Devi J., Tripathi S. and Singh S. (2021). Diversity assessment of spiders in Parvati Aranga Bird Sanctury district Gonda, Uttar Pradesh, India. International Research Journal of Modern Engineering, Technology \& Science. 3(10): 508-515.

18. Singh B.B. and Singh R. (2014). Incidence and biodiversity of rice land spiders (Arthropoda: Arachnida) in northeastern Uttar Pradesh, India. Indo-American Journal of Life Sciences \& Biotechnology. 2(1): 64-89.

19. Singh R. (2021). Faunal Diversity of Tetragnathidae (Araneomorphae: Araneae: Arachnida) in India. International Journal of Biological Innovations. 3 (1): 92-119. https://doi.org/10.46505/IJBI.2021.3109

20. Singh R. and Singh Garima (2020). Diversity of Mygalomorph Spiders (Aranae: Opisthothelae) in India. International Journal 
of Biological Innovations. 2 (2): 178201.ttps://doi.org/10.46505/IJBI.2020.2215

21. Singh R. and Singh G. (2021a). Faunistic diversity of orb-weaver spiders (Araneidae: Araneomorphae: Araneae: Arachnida) in India. International Journal of Biological Environmental Investigations. 2021; 1(2): 62133. doi.org/10.33745/ijbei.2021. v01i02.001

22. Singh R. and Singh G. (2021b). Updated checklist of spider (Arachnida: Araneae) diversity in Haryana, Himachal Pradesh, Punjab, Chandigarh and Delhi (India). Serket. 18(2): 199-228.

23. Singh R. and Singh G. (2021c). Faunal diversity of Spiders (Chelicerata: Araneae) in Bihar and Jharkhand, India. International Journal of Biological Innovations. 3(2):382391. https://doi.org/10.46505/IJBI.2021.3220

24. Singh R. and Singh B.B. (2022a). An updated checklist of spiders (Arachnida: Araneae) of Goa, India. International Journal of Biological Innovations. 4(1): 51-63. https://doi.org/ 10.46505/IJBI.2022.4105.

25. Singh R. and Singh G. (2022b). Faunal diversity of spiders (Chelicerata: Araneae) in Uttar Pradesh and Uttarakhand, India. Arthropods. 11(1): 18-55.

26. Singh R., Singh G. and Singh B. B. (2020). Diversity of Simonid Spiders (Araneae: Salticidae: Salticinae) in India. International Journal of Biological Innovations. 2 (2): 247276. https://doi.org/10.46505/IJBI.2020.2223

27. Singh R., Singh G. and Singh B. B. (2021). Faunal Diversity of Jumping Spiders (Salticidae: Araneae: Arachnida) in India. International Journal of Biological Innovations. 3 (1): 01-37. https://doi.org/ 10.46505/IJBI.2021.3101

28. Tikader B.K. (1980). Araneae: Thomisidae (Crab-spiders). In: Fauna of India Vol. 1, Part 1 (Ed. Director), Zoological Survey of India, Kolkata. 247p.

29. Tikader B.K. (1982). Spiders: Araneae. In: The Fauna of India, Vol. 2, Part 1 Family
Araneidae (=Argiopidae) Typical OrbWeavers (Ed. Director), Zoological Survey of India, Kolkata. 293p.

30. Tikader B.K. (1987). Handbook of Indian Spiders. Zoological Survey of India, Kolkata. 251p.

31. Tikader B.K. and Malhotra M.S. (1980). Araneae: Lycosidae (Wolf-spiders). In: The fauna of India, Volume 1, Part 2. Zoological Survey of India, Kolkata. 248-447p.

32. Uetz G.W., Halaj J. and Cady A.B. (1999). Guild structure of spiders in major crops. Journal of Archnology. 27: 270-280.

33. Vankhede G.N. (2011). Conservation of Spiders in India. ENVIS Bulletin : Wildlife $\mathcal{\sigma}$ Protected Areas. 14: 54-59.

34. Vasconcellos-Neto J., Messas Y.F., Souza H.S., Villanueva-Bonila G.A. and Romero G.Q. (2017). Spider-Plant Interactions: An Ecological Approach. In: Behaviour and Ecology of Spiders. Viera C. and Gonzaga C.M.O. (Eds.), Springer International Publishing. pp165-214. 10.1007/978-3-31965717-2_7.

35. Verma A.K. (2017). Necessity of ecological balance for widespread biodiversity. Indian Journal of Biology. 4(2): 158-160.

36. Verma A.K. and Prakash S. (2020). Status of Animal Phyla in different Kingdom Systems of Biological Classification. International Journal of Biological Innovations. 2(2): 149154. doi.org/10.46505/IJBI.2020.2211

37. WSC. (2022). World Spider Catalog. Version 23.0. Natural History Museum Bern, online at http://wsc.nmbe.ch, accessed on 15 February, 2022.

38. Zvaríková M., Prokop P., Zvarík M., Ježová Z., Medina-Jerez W. and Fedor P. (2021). What makes spiders frightening and disgusting to people? Frontiers in Ecology and Evolution. 9: e694569. doi: 10.3389/ fevo.2021.694569. 